\title{
How Easy Is an Easy Case for a Complainant? Comment on US-Zeroing (Korea) DS402
}

\author{
JORGE A. HUERTA-GOLDMAN * \\ Carouge, Switzerland
}

\begin{abstract}
This article is about how easy a WTO case is when the defendant concedes the claims, the description of the facts, and the evidence presented by the complainant. In US-Zeroing (Korea), the United States did just that. We explore whether Korea obtained any additional benefit by having an easy case. We identified some small benefits at the preparation stage of the case arising from the favourable precedents and shorter time frames only at the Panel stage. There were, however, some additional costs for the complainant stemming from the Panel's reasoning when it addressed case law. In our opinion, benefits were few. Korea was obliged in any case to engage in two years of multilateral procedures before three old measures, which were not defended by the defendant, were revoked.
\end{abstract}

At the 2012 American Law Institute conference on WTO law in Florence, I discussed the case US-Zeroing (Korea) ${ }^{1}$ presented by Prusa and Rubini. I developed two issues. First, how easy is a dispute where the defendant has conceded the challenge by the complainant? Second, to what extent can WTO legal remedies be applied retrospectively? The two questions are closely related. The first issue explores whether Korea obtained any additional benefit by having an easy case where the defendant conceded the complaint-i.e., US-Zeroing (Korea). As the benefit is small, the second issue takes on greater relevance: whether WTO legal remedies may be applied retrospectively so as to cover part of the consequences of the illegal measure, especially in cases where even the defendant conceded the complaint. This article is about the first element. The second is addressed in a forthcoming separate article.

In US-Zeroing (Korea), the United States (US) knew before the judgment that the measure was WTO illegal. This is confirmed by the fact that it conceded the

\footnotetext{
*Email: jahg@tilpa.ch.

The author is a law practitioner and researcher on trade and investment (www.tilpa.ch). The opinions expressed in this work are entirely those of the author, and he alone is responsible for the accuracy of the information. We would like to thank participants at the ALI Conference on WTO Law 2012, EUI, Florence, Italy, for their comments and guidance in writing this article. Also, we would like to thank Peter Bennett.

1 United States-Use of Zeroing in Anti-Dumping Measures Involving Products from Korea, WT/DS402/R, adopted 24 February 2011 (hereafter, US-Zeroing (Korea)).
} 
issues of law and the issues of fact presented by Korea in that dispute. Despite that, the US maintained the anti-dumping (AD) duties and let Korea undertake the WTO Dispute Settlement (DS) process before revoking the AD orders.

Korea claimed that the US applied zeroing in the three original investigations of products coming from Korea. It alleged violation of Article 2.4.2 of the ADA through the use of zeroing in the original investigations when determining the dumping margin through the methodology of weighted average to weighted average. ${ }^{2}$ The US did not contest Korea's description of the zeroing methodology, the evidence, or the legal claim. ${ }^{3}$ Also, strong and clear precedents supported Korea's case of violation. ${ }^{4}$

\section{Upstream}

Korea had to prepare evidence, study the measures, develop the claims, and assess the case law before initiating the dispute. At the time of preparation of the case, Korea did not know whether the US would concede its complaint. Had Korea not presented the case properly, most probably the US would not have conceded the complaint. This suggests that the case was not easier for Korea at the preparatory stage.

But, Korea had the guidance from strong precedents that have ruled on identical measures and claims. ${ }^{5}$ Certainly, this was an advantage when determining sufficiency of evidence, and clarity of claims. But it was the precedents that gave advantage and not the US-Zeroing (Korea) dispute itself.

\section{Time table}

First, the Panel eliminated the second substantive meeting with the parties after consulting with them. This made the case shorter for Korea. We consider this to be a benefit. ${ }^{6}$

2 The products concerned were stainless-steel plate in coils ('SSPC'), stainless-steel sheet and strip in coils ('SSSS'), and diamond sawblades. See US-Zeroing (Korea), paras. 1.1, 2.1, and 7.26.

3 A similar situation with respect to uncontested claims occurred in Panel Report, United States - Antidumping Measures on Certain Shrimp and Diamond Sawblades from China, WT/DS422/R and Add.1, adopted 23 July 2012. The Panel noted, at para. 7.5, that: 'the panels in US - Shrimp (Ecuador) and, subsequently, US - Shrimp (Thailand), US - Anti-Dumping Measures on PET Bags, and US - Zeroing (Korea) were presented with a similar situation. Indeed each of these panels examined claims, unopposed by the United States, that were virtually identical.'

4 See Panel Report in US-Zeroing (Korea), paras. 1.1, 3.2, and 7.27 and US communication dated 9 December 2011 (WT/DS402/7). Korea's request for consultations was presented on 24 November 2009. Its request for a Panel is from 8 April 2010. Finally, the US revoked the AD order on Steel Plate and Steel Sheet in November 2011, and on Sawblades in December 2011.

5 See Panel Report in US-Zeroing (Korea), paras. 3.2 and 7.27.

6 See ibid., para. 1.6. 
Figure 1. Overall time frames

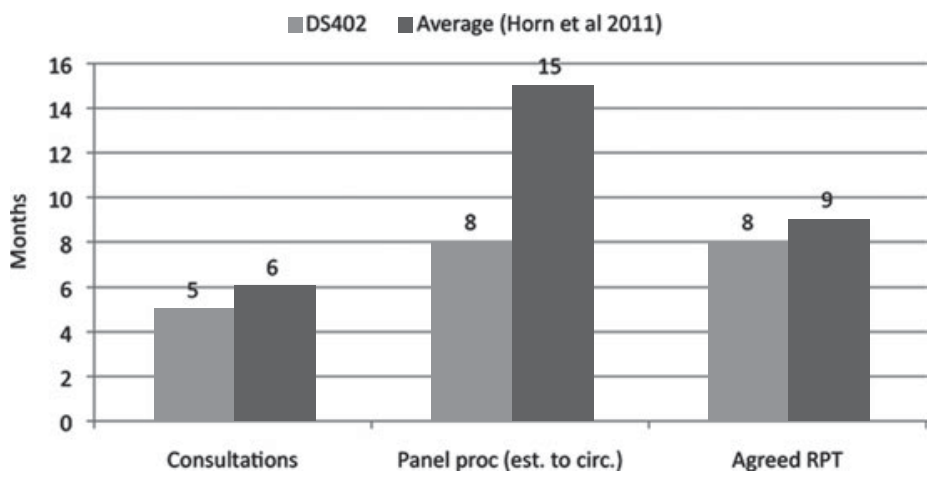

Note: 'Panel proc (est. to circ.)' means Panel proceeding (establishment to circulation).

Second, Figure 1 shows the overall time frames of the case at issue and the average of WTO DS cases (based on information from Horn et al., 2011). ${ }^{7}$ The only period that is significantly shorter is the Panel stage. Seven months less is a benefit for Korea. But, no significant benefit is shown at the consultations stage, or after a reasonable period of time (RPT).

\section{Adjudication}

There are some additional costs for Korea in the adjudicative Panel process. First, the $\mathrm{AB}$ has indicated that adjudicators may use uncontested facts to draw a ruling on the matter. ${ }^{8}$ But, the Panel decided not to follow such practice in order to comply with the need for an objective assessment of the matter under Article 11 of the DSU. If the $\mathrm{AB}$ uses undisputed facts to complete the legal analysis, this may suggest that the $\mathrm{AB}$ does not consider that a violation of Article 11 of the DSU occurs when a Panel draws on undisputed facts.

Second, the Panel decided not to categorize this undisputed matter as a mutually agreed solution (MAS), as it was concerned to meet the obligation to make an objective assessment under Article 11 of the DSU. This interpretation by the Panel may wrongly suggest that if the parties agree that there is a violation and the Panel reflects this in the Report, there is a risk of violation of Article 11 of the DSU. Further research is needed on the scope of MAS and Panels' treatment of

7 The averages are based on: Henrik Horn, Louise Johannesson, and Petros C.Mavroidis (2011), 'The WTO Dispute Settlement System 1995-2010: Some Descriptive Statistics', 45:6 Journal of World Trade, 1107-1138.

8 See the Appellate Body Report in European Communities - Export Subsidies on Sugar, WT/DS265/ AB/R, WT/DS266/AB/R, WT/DS283/AB/R, adopted 19 May 2005, DSR 2005:XIII, 6365, at para. 337. It 'has declined to complete the legal analysis where "the factual findings of the panel and the undisputed facts in the panel record" did not provide a sufficient basis for the legal analysis by the Appellate Body' (emphasis added). 
Table 1. Time frames on implementation

\begin{tabular}{lcc}
\hline \hline Order & Initiation to revocation of AD & Req. Consul. $^{1}$ to revocation of AD \\
\hline Steel Plate $^{2}$ & 13 years 7 months & 2 years \\
Steel Sheet $^{3}$ & 13 years 4 months & 2 years \\
Sawblades $^{4}$ & 6 years 7 months & 2 years 1 month \\
\hline \hline
\end{tabular}

Notes:

1 Korea's request for consultation is from November 2009.

2 For Steel Plate, the AD order was initiated in April 1998, and the revocation took place in November 2011.

3 For Steel Sheet, the AD order was initiated in July 1998, and the revocation took place in November 2011.

4 For Sawblades, the AD order was initiated in June 2005, and the revocation took place in December 2011.

Source: Based on Thomas S. Prusa and Luca Rubini (2013), United States - Use of Zeroing in AntiDumping Measures Involving Products from Korea: It's déjà vu all over again, World Trade Review, this issue.

undisputed facts - already accepted by the $\mathrm{AB}$ - and undisputed claims, such as the case at issue.

Finally, the Panel added a new step in determining a WTO violation. The Panel's test is whether the measure violates WTO law (see for instance Articles 7 and 19 of the DSU). The Panel covered that in two sections of its Report: whether the US zeroed (para. 7.21 et seq.) and whether the zeroing methodology used is inconsistent with Article 2.4.2 of the Antidumping Agreement (para. 7.28 et seq.). But, it included an additional section on whether the methodology used by the US in this case was the same as the one used in US-Softwood Lumber V, which represented the strong precedent (para. 7.23 et seq.). It seems that the Panel inserted an additional step for cases with strong precedents: the need to prove that the two measures are the same. If this practice is adopted in future cases, there will be a two-step process for cases without strong precedents and a three-step process for cases with strong precedent.

\section{Implementation}

Table 1 shows the time frames on implementation. Two years from the request for consultations to the revocation of the order seems a short period. As noted in Table 1 above, the Panel procedure was faster than the average, which was a benefit for Korea. But, this is still far from perfect as revocation took two years of multilateral procedures despite the fact that there was no disagreement by the parties that the measure was WTO-illegal.

Finally, for two products, 13 years elapsed between the time of initiation of the $\mathrm{AD}$ investigation and the revocation of the $\mathrm{AD}$ order; and, for the other product, it was six years. The date of initiation of the AD order is relevant in light of 
Article 5.8 of the Anti-Dumping Agreement (ADA) that: '[a]n application ... shall be rejected and an investigation shall be terminated promptly as soon as the authorities concerned are satisfied that there is not sufficient evidence of ... dumping'. The investigations were not recent.

\section{Conclusion}

Korea was guided by a strong precedent in its favour - very useful as complainant and obtained a shorter Panel process. At the adjudicative stage, it had some extra costs. The costs do not appear to be significant in an easy case, but in complex cases they could be onerous for a complainant. Finally, two years of multilateral proceedings to revoke three old measures, where the defendant conceded the complaint, calls for an assessment of WTO legal remedies. I agree with Prusa and Rubini that there is a need for more studies on whether the WTO legal remedies may be applied retrospectively. 